\title{
COMPARATIVE STUDY OF THE RELATIONSHIP BETWEEN THE QUANTITIES OF ACTIVE 3- $\beta$-HSDH \\ AND 17- $\beta$-HSDH CELLS IN THE OVARIES OF MUSCOVY AND PEKING DUCKS
}

\author{
A. DERAY et L. GOMOT \\ Laboratoive de Zoologie, \\ Équipe de Recherche associée au C. N. R. S., no 229, \\ 25030 Besançon Cedex
}

In Muscovy and Peking domestic female ducks, the cells showing a $\Delta^{5}-3-\beta$-hydroxysteroid dehydrogenase activity were localized at the theca interna level of the follicles, whereas the cells with an active $17-\beta$-hydroxysteroid dehydrogenase enzyme were spread under the germinative epithelium. The relationship established between these two cellular categories was quite different and characteristic for each species of female ducks.

\section{HISTOLOGICAL AND CYTOLOGICAL STUDY \\ OF THE TESTIS AND GENITAL TRACTS \\ OF MUSCOVY DUCKS (CAIRINA MOSCHATA L.) DURING SEXUAL ACTIVITY}

\author{
C. R. MARCHAND et L. GOMOT \\ Laboratoire de Zoologie, \\ Équipe de Recherche associée au C. N. R. S. $n^{\circ} 229$ \\ 25030 Besançon Cedex
}

I. The cellular associations of the seminal epithelium were studied on semi-fine sections coloured with toluidine blue. The observations are in quite good agreement with what Y. CLERMONT (1958) found in the Peking duck (Anas platyrhynchos L.).

In the interstitial spaces, the Leydig cells, with large nucleolli and with cytoplasm filled with lipids, formed large islets.

2. The genital tracts were observed on $5 \mu$ paraffin sections.

Four types of ducts can be seen in the epididymis :
a) rete testis ducts ;
b) efferent ducts ;
c) connecting ducts ;
d) epididymis ducts. 